\title{
Teologi, filsafat keilahian, dan spiritualitas: Problematika lokus ilmu teologi dalam sistem pendidikan nasional Indonesia
}

\author{
Simon Rachmadi \\ Sekolah Tinggi Filsafat Theologi Jakarta, DKI Jakarta \\ simon.rachmadi@gmail.com
}

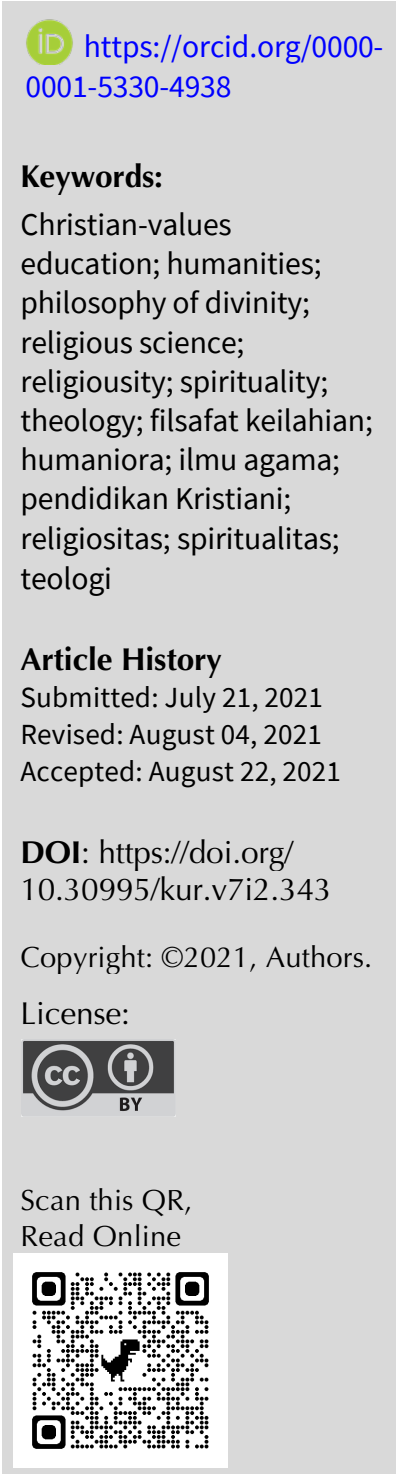

Abstract: This article criticizes the way of thinking of the Indonesian Statute of Higher Education known as “Undang-undang No. 12 Tahun 2012”, which puts the academic discipline of theology into the realm of religious science which must be fostered, coordinated, and supervised by the Ministry of Religion. This placement has been brought about injudiciously regardless the reality on the ground where-for many years in Indonesia-the efforts of doing higher education on theology have been carried out by many Christian communities using their consideration freely: whether to have their theological schools registered by the Ministry of Religion or whether to have them registered by the Ministry of Education. Evaluating the philosophy of the Statute, this article argues about a misconception regarding the idea of "theology" in the Indonesian system of national education. By showing the misconception, this article suggests an alternative direction for public policy: that the academic discipline of theology should be explicitly recognized in Indonesia not only as a science of religious life registered by the Ministry of Religion but also as a science of humanities registered by the Ministry of Education.

\begin{abstract}
Abstrak: Artikel ini menghadirkan kritik atas cara berpikir UU No. 12 Tahun 2012 yang meletakkan ilmu teologi ke wilayah rumpun ilmu agama yang harus dibina, dikoordinasi, dan diawasi oleh Kementerian Agama. Tampaknya, peletakan ini dilakukan secara sembrono tanpa memerhatikan kenyataan lapangan yang menunjukkan bahwa selama bertahun-tahun usaha pengembangan ilmu teologi di Indonesia telah dilakukan oleh masyarakat Kristen dengan pilihan bebas: apakah hendak dikembangkan di bawah binaan Kementerian Agama ataukah di bawah binaan Kementerian Pendidikan. Dalam artikel ini, kritik digulirkan dengan memperlihatkan adanya miskonsepsi-pada cara berpikir undang-undang tersebut-atas ilmu teologi. Dengan memperlihatkan miskonsepsi itu, artikel ini bermaksud menunjuk suatu arah alternatif bagi kebijakan publik: supaya disiplin ilmu teologi tidak dengan semena-mena diletakkan di wilayah rumpun ilmu agama yang dibina oleh Kementerian Agama namun juga diakui secara eksplisit di Indonesia sebagai wilayah rumpun ilmu humaniora yang dibina oleh Kementerian Pendidikan.
\end{abstract}

\section{Pendahuluan}

Kedudukan ilmu teologi di dalam sistem pendidikan nasional Indonesia secara perlahan-lahan telah bergeser. Lokus ilmu teologi menjadi tidak seperti yang dimengerti oleh kalangan Kristen selama ini. Hal ini bermula dari, antara lain, gejala dualisme pendidikan teologi: apakah program studi teologi itu akan dikelola di bawah Kementerian Agama ataukah Kementerian Pendidikan. ${ }^{1}$

${ }^{1}$ Jozef M.N. Hehanussa, “Dualisme Tata Kelola Pendidikan Tinggi Teologi Indonesia," Kompas, 2017. 
Dualisme pendidikan teologi ini mungkin adalah bagian dari arus besar yang tengah melanda dunia saat ini di mana "peradaban Islam" tampaknya semakin mengklaim keunikan wilayah "ilmu agama" terhadap wilayah iptek Barat. ${ }^{2}$ Di tengah gejala dualisme itu, sistem pendidikan nasional Indonesia kemudian memahami ilmu teologi dalam cahaya tradisi Islam: bahwa lokus teologi adalah seperti kedudukan ilmu agama yang dikembangkan di dunia madrasah dan pesantren. Bagi kalangan Kristen hal ini tentu saja menjadi terasa aneh.

Selama ini tampaknya orang enggan untuk membicarakan dualisme pendidikan teologi di dalam sistem pendidikan nasional karena hal itu sedikit banyak akan bersinggungan dengan perbedaan cara pikir yang mendasar antara agama Kristen dengan agama Islam. Keengganan ini dapat dimaklumi, namun jika dibiarkan berlarut-larut justru akan menimbulkan miskonsepsi yang semakin besar dan menyulitkan proses dialog yang lebih komunikatif.

Untuk membicarakan dualisme tersebut, dalam rangka menjernihkan miskonsepsi yang terjadi dalam sistem pendidikan nasional Indonesia, artikel ini bertujuan untuk memaparkan kompleksitas dan kedalaman ilmu teologi untuk menimbang-nimbang lokus penempatannya: apakah ada di wilayah ilmu agama ataukah di wilayah humaniora. Ilmu teologi bukanlah sekadar ilmu yang melulu bicara soal agama, tetapi juga bicara soal kritik terhadap agama dengan aneka paham yang dianggap suci di dalamnya. Wacana ilmu teologi dapat mengkritik klaim suci/ absolut atas suatu paham agama yang mengatakan—misalnya — bahwa Yang Ilahi itu harus selalu dibicarakan sebagai Yang Mahakuasa; sebab, Yang Ilahi itu ternyata juga dapat dilihat sebagai Yang Mahamampu-hadir dalam segala keadaan termasuk dalam kondisi Maharapuh. ${ }^{3}$ Dalam posisi tersebut, ilmu teologi dapat berfungsi sebagai kritik terhadap ke-"sok-tahu"-an agama. Tanpa mereduksi kedalaman iman, ilmu teologi dapat dimanfaatkan untuk menanggulangi radikalisme agama.

\section{MetOde}

Metode yang ditempuh oleh artikel ini adalah memeriksa kronologi perundang-undangan yang terkait dengan istilah teologi pada kurun waktu dua dasawarsa terakhir. Tujuannya adalah melihat corak masalah dan duduk perkara yang melatar-belakangi terjadinya miskonsepsi atas istilah teologi itu. Sesudah itu, artikel ini mencoba memperlihatkan kedalaman ilmu teologi dengan membahas kompleksitasnya: viz. (a) fenomena epistemologi dikotomis antara agama wahyu versus agama duniawi; (b) kedudukan ilmu teologi terhadap isu religiusitas dan watak ilmu teologi sebagai refleksi iman; (c) kedudukan ilmu teologi di wilayah filsafat keilahian; dan, (d) kedudukan ilmu teologi terhadap isu spiritualitas.

Berdasarkan wawasan akan kompleksitas tersebut akan coba diusulkan suatu rekapitulasi kreatif. Ilmu teologi memang bersifat penuh kritik, namun hal itu dapat berguna untuk memperdalam iman dan agama. Ilmu teologi itu bermanfaat bukan saja untuk memfasilitasi orang agar lebih beragama tetapi juga untuk menolongnya supaya lebih arif dalam beragama. Rekapitulasi kreatif ini akan didekati dengan tiga parameter tematis: teologi, filsafat keilahian, dan spiritualitas.

\section{Hasil dan Pembahasan}

\section{Teologi}

\section{Situasi Ilmu Teologi dalam Perundang-undangan di Indonesia}

Menurut catatan Armada Riyanto, pada tahun 1996 terbitlah Keputusan Menteri Pendidikan dan Kebudayaan No. 0359/U/1996 yang menegaskan pengakuan formal tentang keberadaan ilmu

6.

${ }^{2}$ Simon Rachmadi, "Theologia in Loco" di tengah Jalinan Antar-peradaban (Jakarta: BPK Gunung Mulia, 2019),

\footnotetext{
${ }^{3}$ Joas Adiprasetya, Gereja Pascapandemi Merengkuh Kerapuhan (Jakarta: BPK Gunung Mulia, 2021), 14.
} 
teologi sebagai program studl. ${ }^{4}$ Oleh keputusan menteri ini, ilmu teologi ditempatkan pada kedudukan yang sejajar dengan ilmu-ilmu sejarah, filsafat, religi, antropologi budaya, dan seterusnya.

Beberapa tahun kemudian, yaitu pada tahun 2003, terbitlah UU 20/2003 tentang Sistem Pendidikan Nasional. Di dalam undang-undang ini dikenallah dua istilah kunci: "pendidikan agama" (Pasal 12 etc.) dan "pendidikan keagamaan" (Pasal 30). Istilah pendidikan agama menunjuk kepada penyelenggaraan mata-kuliah/pelajaran agama, di dunia persekolahan yang asumsi pedagogisnya bersifat umum/sekuler, dengan tujuan: pembentukan kompetensi iman, takwa, akhlak mulia. ${ }^{5}$ Sedangkan, istilah pendidikan keagamaan menunjuk kepada jenis persekolahan yang asumsi pedagogisnya didasarkan pada kekhasan suatu tradisi agama tertentu, sebagaimana terwujud — misalnya_dalam keberadaan madrasah dan pesantren. Undang-undang ini bermaksud memperbarui sistem pendidikan nasional dengan cara menghapus diskriminasi terhadap "pendidikan keagamaan" supaya lulusan madrasah dan pesantren dapat melanjutkan ke jenjang pendidikan tinggi yang sifatnya umum. ${ }^{6}$

Untuk mengimplementasikan undang-undang tentang sistem pendidikan nasional tersebut, pada tanggal 5 Oktober 2007, terbitlah PP 55/2007 tentang Pendidikan Agama dan Pendidikan Keagamaan. Dalam PP ini diatur sedemikian rupa: (a) supaya setiap peserta didik dapat menerima pendidikan agama sesuai dengan agama yang dianutnya ${ }^{7}$; dan, (b) supaya pendidikan keagamaan dapat diselenggarakan bukan hanya oleh kalangan Islam tetapi juga oleh kalangan agama non-Islam. ${ }^{8}$ Dalam PP ini muncullah istilah "teologi" untuk menyebut wujud pendidikan keagamaan di lingkungan Kristen. Namun, pemakaian istilah teologi dalam PP ini terasa "janggal". Dalam PP 55/2007 Pasal 29, digariskan bahwa pendidikan keagamaan Kristen terdiri dari: SDTK (Sekolah Dasar Teologi Kristen), SMPTK (Sekolah Menengah PertamaTeologi Kristen), SMAK (Sekolah Menengah Agama Kristen), SMTK (Sekolah Menengah Teologi Kristen). ${ }^{9}$ Padahal, kalangan Kristen tidak pernah mengenal adanya bentuk-bentuk pendidikan keagamaan macam itu.

Untuk mengimplentasikan PP tersebut di kalangan Kristen, diterbitkanlah dua peraturan menteri agama: yaitu Permenag 16/2010 (tentang Pengelolaan Pendidikan Agama pada Sekolah) ${ }^{10}$ dan Permenag 7/2012 (tentang Pendidikan Keagamaan Kristen). Di dalam Permenag yang terakhir itu ada sederetan nama matapelajaran dan nama matakuliah yang dikelompokkan ke dalam wilayah pendidikan keagamaan Kristen. Digariskan bahwa "Kurikulum keagamaan Kristen pada SDTK, SMPTK, SMTK/SMAK...ppaling sedikit memuat: Dogmatika, Ilmu Pengetahuan Alki-

${ }^{4}$ Armada Riyanto, "Filsafat Divinitas (Keilahian) atau 'Teologi,'” Jurnal Teologi 4, no. 1 (2019): 66

${ }^{5}$ Penjelasan UU 20/2003, Pasal 37 ayat 1.

${ }^{6}$ Lihat pernyataan eksplisit akan hal ini dalam Penjelasan UU 20/2003 pada bagian (I. Umum) di akhir paragraf dua: "Pembaharuan system pendidikan juga meliputi penghapusan diskriminasi antara pendidikan yang dikelola pemerintah dan pendidikan yang dikelola masyarakat, serta pembedaan antara pendidikan keagamaan dan pendidikan umum"

7 Penjelasan PP 5/2007, Pasal 4 ayat 1, mengatakan: "Kurikulum pendidikan agama bagi peserta didik yang beragama berbeda dengan kekhasan agama satuan pendidikan menggunakan kurikulum pendidikan agama sesuai dengan agama yang dianut peserta didik."

${ }^{8}$ PP 5/2007, Bab 1, Pasal 1 ayat 4-8. Pendidikan keagamaan Islam mencakup dua jenis: yaitu diniyah dan pesantren. Pendidikan keagamaan Hindu mencakup dua jenis: yaitu pasraman dan pesantian. Pendidikan keagamaan Buddha mencakup satu jenis: yaitu pabbajja. Pendidikan keagamaan Khonghucu mencakup satu jenis: yaitu shuyuan. Pendidikan keagamaan Kristen dan Katolik tidak dirumuskan cakupannya di dalam bagian Ketentuan Umum, namun langsung diatur di dalam Pasal 27-37.

${ }^{9}$ Rupanya, oleh PP ini, istilah "teologi" dianggap sebagai istilah khas yang menunjuk "ilmu keagamaan Kristen". Bandingkan dengan istilah "ilmu agama" yang dikembangkan untuk mengisi "pendidikan keagamaan Islam" yang dikembangkan di madrasah dan pesantren. Dalam cara berpikir ini, "teologi" adalah ilmu agama yang dikembangkan di wilayah pendidikan keagamaan.

${ }^{10}$ Oleh peraturan menteri ini digariskan, antara lain, kewajiban sekolah swasta untuk menyediakan guru pendidikan agama yang sesuai dengan agama yang dianut oleh peserta didik. Guru agama tersebut "harus memiliki kompetensi pedagogik, kepribadian, sosial, profesional, dan kepemimpinan" (Pasal 16 ayat 1). Kewajiban ini menyulitkan sekolah-sekolah swasta yang kemampuan finansialnya pas-pasan. Sekolah-sekolah swasta Kristen pada akhirnya hanya menerima murid yang agamanya sesuai dengan kekhasan lembaga pendidikan mereka. Masyarakat pun semakin tersekat oleh perbedaan agama. 
tab, Sejarah Gereja/Sejarah Suci, Etika, Pembentukan Karakter; dan Pendidikan Agama Kristen" ${ }^{11}$ Isi kurikulum yang selama ini dikerjakan di wilayah pendidikan tinggi teologi kini-oleh PP tersebut—hendak diimplementasikan ke wilayah "pendidikan keagamaan Kristen" sejak jenjang sekolah dasar.

Kedua Permenag tersebut di atas mengatur pendidikan keagamaan Kristen dengan cara pikir PP 55/2007. Mereka memandang bahwa istilah "teologi" adalah terminologi pendidikan keagamaan Kristen. Walaupun tidak sejalan dengan apa yang ada di lapangan, yaitu di dunia pendidikan yang diusahakan oleh kalangan Kristen, cara pandang itu akhirnya berlanjut terus menjadi UU 12/2012 tentang Pendidikan Tinggi.

Secara kategoris, undang-undang 12/2012 itu menetapkan enam rumpun iptek yang disebut: rumpun ilmu agama, rumpun ilmu humaniora, rumpun ilmu sosial, rumpun ilmu alam, rumpun ilmu formal, dan rumpun ilmu terapan. Di dalam kategorisasi itu, ilmu teologi diletakkan ke dalam rumpun ilmu agama yang merupakan: "rumpun Ilmu Pengetahuan yang mengkaji keyakinan tentang ketuhanan atau ketauhidan serta teks-teks suci agama antara lain...ilmu pendidikan agama Kristen, ilmu pendidikan agama Katholik, teologi, misiologi, konseling pastoral..."12

Berdasarkan daftar nama ilmu di rumpun "ilmu agama" dalam UU 12/2012 tersebut di atas, pihak Menteri Agama kemudian merevisi Permenag 7/2012 dengan menerbitkan Permenag 27/2016. Tujuannya adalah untuk melengkapi daftar matapelajaran yang menjadi kurikulum "pendidikan keagamaan Kristen" berdasarkan cakupan daftar nama ilmu yang sesuai dengan UU 12/2012. Dalam Permenag 27/2016 ini dinyatakan: bahwa kekhasan kurikulum SDTK (Sekolah Dasar Teologi Kristen) adalah pada tambahan matapelajaran: Pengetahuan Alkitab, dan Pendidikan Karakter Kristen ${ }^{13}$; bahwa kekhasan kurikulum SMPTK (Sekolah Menengah Pertama Teologi Kristen) adalah pada tambahan matapelajaran: Pengetahuan Alkitab, Pendidikan Karakter Kristen, dan Sejarah Gereja/Suci ${ }^{14}$; bahwa kekhasan kurikulum SMTK (Sekolah Menengah Teologi Kristen) adalah pada tambahan matapelajaran: Pengetahuan Alkitab, Etika Kristen, Sejarah Gereja/Suci, Dogmatika, Hermeneutika, dan Misiologi ${ }^{15}$; bahwa kekhasan kurikulum SMAK (Sekolah Dasar Teologi Kristen) adalah pada tambahan matapelajaran: Pengetahuan Alkitab, Pendidikan Karakter Kristen, dan Sejarah Gereja/Suci, dengan ditambah beberapa bidang ilmu bahasa. ${ }^{16}$

Dari hal-hal tersebut di atas kiranya dapat disimpulkan bahwa sistem pendidikan nasional di Indonesia sama sekali tidak memahami alam kerohanian dan tradisi pendidikan keagamaan di kalangan umat Kristiani. Berbeda dengan kalangan Islam yang mengenal dunia pesantren dan aneka madrasah, kalangan Kristen tidak pernah mengenal adanya wilayah "pendidikan keagamaan" yang terpisah dari wilayah "pendidikan umum" sejak jenjang pendidikan dasar. Untuk mengurai benang kusut atas persoalan tersebut kiranya istilah "teologi" itu perlu dianalisis lebih jauh kedalamannya, khususnya dalam kaitannya dengan epistemologi (paham keilmuan) yang memilah "ilmu agama" dan ilmu-ilmu non-agama di dua wilayah yang saling berseberangan.

\section{Analisis: Epistemologi Dikotomis "Agama Wahyu" vs. "Agama Duniawi"}

Di Indonesia, cara pandang dikotomis yang memilah wilayah "surga" dan "dunia" masih banyak dijumpai di tengah masyarakat. Salah satunya adalah cara pandang tentang tipologi agama yang

\footnotetext{
11 Permenag 7/2012, Pasal 7 ayat 2

${ }^{12}$ Penjelasan UU 12/2012, Pasal 10 ayat 2.a. Dengan deskripsi ini menjadi terlihat bahwa istilah 'rumpun ilmu agama' adalah isi dari 'pendidikan keagamaan' yang dideskripsikan oleh UU 20/2003, Pasal 30 ayat 2: “Pendidikan keagamaan berfungsi mempersiapkan peserta didik menjadi anggota masyarakat yang memahami dan mengamalkan nilai-nilai ajaran agamanya dan/atau menjadi ahli ilmu agama."

${ }_{13}^{13}$ Permenag 27/2016, Pasal 8 ayat 1.

${ }^{14}$ Permenag 27/2016, Pasal 8 ayat 2.

${ }^{15}$ Permenag 27/2016, Pasal 8 ayat 3.

${ }^{16}$ Permenag 27/2016, Pasal 9 ayat 4 dan 5.
} 
diadopsi dari pemikiran seorang ilmuwan Pakistan Abdullah al-Masdoosi. ${ }^{17}$ Menurut ilmuwan Pakistan itu, keragaman agama di dunia dewasa ini dapat dilihat sebagai distingsi tiga oposisi: (a) agama wahyu vs. agama non-wahyu; (b) agama misionaris vs. agama-nonmisionaris; dan (c) agama rasial vs. agama universal. ${ }^{18}$ Dalam distingsi itu diandaikan bahwa kedudukan suatu agama lebih unggul daripada yang lain karena memuat sifat-sifat: universal, non-kolonial, dan bersumber dari wahyu ilahi.

Dengan asumsi tersebut, keunggulan wilayah ilahi akan selalu diposisikan mengatasi segala wilayah keilmuan. Apa-apa yang dibicarakan di wilayah keilmuan itu pada dasarnya akan membuktikan segala hal yang dinyatakan oleh kitab suci; sekalipun banyak hal yang dikatakan oleh kitab suci sulit diverifikasi kebenarannya oleh wacana-wacana di wilayah keilmuan. Misalnya: bahwa jalannya sejarah dunia itu membuktikan warta kitab suci ${ }^{19}$; bahwa jalannya ritual dan institusi di dunia manusia itu sesuai dengan kitab suci ${ }^{20}$; bahwa dunia arkeologi itu memuat temuan-temuan yang membuktikan eksistensi historis dari kisa-kisah dalam kitab suci ${ }^{21}$; sebab, kekayaan makna kitab suci tidak pernah bisa dikemas secara sempurna selain dengan memakai pendekatan simbolik yang "mengungkapkan sesuatu tetapi menginginkan makna lain". ${ }^{22}$ Dengan penalaran macam itu maka orang pun dapat berargumentasi:

Dalam Islam, akal memiliki posisi yang sangat mulia. Meski demikian, bukan berarti akal diberi kebebasan tanpa batas dalam memahami agama. Islam memiliki aturan yang menempatkan akal sebagaimana mestinya. Bagaimanapun, akal yang sehat akan selalu cocok dengan syariat Allah swt, dalam masalah apa pun. ${ }^{23}$

Epistemologi dikotomis macam itu juga terdapat di kalangan Kristen yang mengasumsikan: kebenaran rasional vs. "pengetahuan sejati yang bersumber dari pengenalan akan Allah". Kebenaran rasional dianggap bersifat semu karena hanya bertumpu pada akal budi manusiawi, sedangkan pengetahuan rohani dianggap bersifat sejati karena bersumber dari aktivitas pewahyuan ilahi melalui kitab suci. ${ }^{24}$ Dikotomi ini bersumber dari gagasan tentang revealed religion (agama wahyu) yang jejak-jejaknya dapat ditemukan sejak berabad-abad yang laluantara lain-dalam pemikiran seorang politikus abad ketujuh belas Thomas Dudley, ${ }^{25}$ dan dalam pemikiran seorang filfuf terkenal di abad kesembilan belas Friedrich Hegel. ${ }^{26}$ Gagasan tentang agama wahyu itu mengasumsikan adanya ilmu tertinggi yang bersumber dari akses langsung terhatap Yang Ilahi. Gagasan ini sempat menciptakan pendapat populer yang memandang bahwa ilmu teologi adalah puncak dari segala macam iptek; ilmu teologi adalah the queen of sciences. ${ }^{27}$

\footnotetext{
17 Ahmad Remi, "Klasifikasi Agama," Majelis Penulis: Majelis Ukhuwah Penulis Bersyariah, 2012, https://majelispenulis.blogspot.com/2012/04/klasifikasi-agama.html (diakses 28 Juli 2021).

${ }^{18}$ Abu Tamrin, "Relasi Ilmu, Filsafat dan Agama dalam Dimensi Filsafat Ilmu," Salam: Jurnal Sosial dan Budaya Syar-i 6, no. 1 (2019): 88.

${ }^{19}$ Misri A Muchsin, "Nilai Filosofis Historis dalam Al-Quran," dalamn Kajian Ilmu Sosial dan Humaniora dalam Perspektif Al-Quran, ed. Mukhtaruddin (Syiah Kuala, Banda Aceh: Bandar Publishing, 2016), 19.

${ }^{20}$ Abdul Manan, "Ritual dan Institusi dalam Islam," dalam Kajian Ilmu Sosial dan Humaniora dalam Perspektif Al-Quran, ed. Mukhtaruddin (Syiah Kuala, Banda Aceh: Bandar Publishing, 2016), 38.

${ }^{21}$ Nasruddin AS, "Info Arkeologis dalam Al-Quran," dalam Kajian Ilmu Sosial dan Humaniora dalam Perspektif Al-Quran, ed. Mukhtaruddin (Syiah Kuala, Banda Aceh: Bandar Publishing, 2016), 132.

${ }^{22}$ Fahmi Sofyan, "Gaya Bahasa Kinayah dalam Rethorika Al-Quran: Sebuah Pendekatan Balaghah," dalam Kajian Ilmu Sosial dan Humaniora dalam Perspektif Al-Quran, ed. Mukhtaruddin (Syiah Kuala, Banda Aceh: Bandar Publishing, 2016), 73.

${ }^{23}$ Muhammad Amin, "Kedudukan Akal Dalam Islam," Tarbawi: Jurnal Pendidikan Agama Islam 3, no. 1 (2018): 40

${ }^{24}$ Asumsi dikotomis tersebut antara lain terlihat dari pendapat-pendapat berikut yang mengasumsikan adanya "kebenaran ilahi" yang secara kelihatan dapat langsung dikontraskan dengan kebenaran-kebenaran keilmuan pada umumnya. Bdk. Lase dan Purba 2020, 156-157; Tarigan 2019, 93.

${ }^{25}$ Lih. Samuel Gilman, Revealed Religion: A Dudleian Lecture (Boston: W.M. Crosby and H.P Nichols, 1848), 3.

${ }^{26}$ Lih. William Wallace, Hegel's Philosophy of Mind (Oxfod: Clarendon Press, 1894), 175-180.

${ }^{27}$ Gijsbert van den Brink, "How Theology Stopped Being Regina Scientiarum-and How Its Story Continues," Studies in Christian Ethics 32, no. 4 (July 2019): 443-444.
} 
Dalam kaitannya dengan sistem pendidikan nasional saat ini, eksistensi epistemologi dikotomis tersebut kiranya patut diwaspadai agar tidak menciptakan arus zaman yang membawa situasi negara, bangsa, dan masyarakat ke pusaran irasionalitas zaman kegelapan (dark ages) gara-gara orang dengan mudah mengatasnamakan agama untuk membenarkan opininya. Cara mewaspadai epistemologi dikotomis itu adalah dengan memajukan ilmu-ilmu yang sifatnya menumbuhkan refleksi kritikal. Jika tidak dikurung di wilayah "ilmu agama" untuk keperluan "pendidikan keagamaan" maka ilmu teologi akan dapat berfungsi sebagai sarana penting untuk menumbuhkan aneka refleksi kritikal untuk menjernihkan dikotomi antara "agama wahyu" vs. "agama duniawi. Hal ini akan sangat bermanfaat untuk meredam tumbuhnya arus radikalisme agama.

\section{Analisis: Ilmu Teologi vs. Religiusitas Kristen}

Selain dapat berfungsi kritis, ilmu teologi pun dapat berfungsi sebagai fasilitator pematangan hidup beriman religius. Jika dibayangkan bahwa pendidikan keagamaan Kristen adalah seperti halnya pendidikan keagamaan Islam-yang bentuknya madrasah dan pesantren-maka asumsi kekhasan kurikulumnya adalah pada corak khas pembinaan cara hidup yang diliputi oleh religiositas. Istilah religiositas di sini artinya corak hidup yang bergaul erat dengan religion (agama). Arti "religion" di sini berasal dari gagasan Latin re+legere (yang artinya membaca berulang-ulang) atau re+ligare (yang artinya mengikat berulang-ulang; artinya penuh kedisiplinan). ${ }^{28}$ Melalui kandungan makna macam itu, istilah religiositas menunjuk kepada sikap "religius" yang artinya: penuh komitmen dalam membaca naskah-naskah suci serta membangun hidup yang penuh kedisiplinan. Dalam sejarah tradisi Kristiani, istilah "religius" itu kemudian dikenakan pada sikap keagamaan yang khas: yaitu "bukan biasa-biasa saja" tetapi secara intensif- penuh-kerelaan meninggalkan tatanan hidup sekuler-yang dianggap normal-demi mencari kesempurnaan hidup menurut Injil.

Wujud gerakan "religius" itu macam-macam. Mula-mula, wujudnya adalah persekutuan para "murid Kristus" (disciple) yang rela meninggalkan segala hal untuk mengikuti perjalanan Tuhan Yesus di dunia ini. Gagasan "murid Kristus" macam ini kemudian melahirkan suatu sikap religius Kristen yang isinya adalah kedisiplinan olah diri dan latihan rohani untuk mencari panggilan ilahi yang terasa otentik atas hati nurani seseorang. Gagasan tentang "murid Kristus" ini kemudian melahirkan suatu corak religius yang disebut: ke-murid-Kristus-an (discipleship).

Corak religius ke-murid-Kristus-an (discipleship) ini ada yang moderat tapi ada pula yang ekstrim. Yang moderat muncul dalam wujud kesalehan populer yang teranyam dalam hidup sehari-hari. Yang ekstrim muncul dalam wujud gerakan petapa yang mengasingkan diri ke "luar dunia" (ke padang gurun). Para petapa yang membangun hidup religiusnya secara orang per orang disebut sebagai kaum hermit. Sedangkan para petapa yang membangun hidup religiusnya secara berkelompok disebut sebagai kaum senobit. ${ }^{29}$

Keberadaan para petapa senobit ini mungkin mirip-mirip dengan apa yang dibayangkan oleh kalangan Islam sebagai pesantren atau madrasah. Mereka belajar ilmu "duniawi" pada umumnya dengan diperlengkapi keterampilan hidup praktikal serta disiplin membaca dan mendiskusikan isi kitab suci di bawah bimbingan seorang guru religius atau di bawah suatu program kateketik/pendidikan tertentu. Mereka belajar menjalani hidup sehari-hari secara terampil, disiplin, dan bijaksana, sambil mengasah suara hati dan mencermati pertumbuhan karismakarisma rohani. Dalam praksis macam ini, mereka dapat disebut sebagai para pengikut tarekat hidup religius_-atau sekolah hidup religius.

Namun, satu hal dapat dipastikan: mereka tidak belajar ilmu teologi. Mereka mempelajari berbagai kebiasaan hidup rohani dan tradisi kebijaksanaan religius tertentu, tetapi mereka tidak mempelajari ilmu teologi. Yang mempelajari ilmu teologi pada umumnya bukanlah para

${ }^{28}$ Online Etymology Dictionary, "Religion," n.d. https://www.etymonline.com/search?q=religion (accessed on July 17,2021$)$.

${ }^{29}$ Adolf Heuken, Spiritualitas Kristiani: Pemekaran Hidup Rohani Selama Dua Puluh Abad (Jakarta: Cipta Loka Caraka, 2002), 50. 
pengikut tarekat hidup religius, akan tetapi para skolastik yang diperlengkapi dengan kompetensi sastra, filsafat, dan sejarah yang cukup mendalam. Maka, dapatlah dikatakan di sini bahwa-di dalam tradisi Kristiani-ilmu tentang "religiusitas" (dalam arti hidup rohani, ke-murid-Kristus-an, discipleship) tidaklah sama dengan ilmu teologi. Yang satu lokusnya ada di wilayah pembinaan habitus suara-hati dan karisma rohani; yang lain lokusnya ada di wilayah pembinaan akal budi.

\section{Analisis: Ilmu Teologi dan Refleksi Akal Budi atas Iman}

Apakah ilmu teologi itu? Apakah teologi itu sains ataukah kebatinan? Apakah teologi itu refleksi filsafati ataukah sikap iman yang bertumpu pada naluri keyakinan 'blind leap' (artinya sikap: pokoknya aku percaya)? Jawabnya: teologi mencakup keseluruhannya.

Dengan merujuk pendapat dari beberapa teolog ternama, Alister McGrath mencoba memaparkan kompleksitas ilmu teologi tersebut dengan beberap kalimat di bawah:

"Theology is the science of faith. It is the conscious and methodical explanation and explication of the divine revelation received and grasped in faith" (Karl Rahner).

"Theology may be defined as the study which, through participation in and reflection upon a religious faith, seeks to express the content of this faith in the clearest and most coherent language available" (John Macquarrie).

"Theology is science seeking the knowledge of theWord of God spoken in God's work-science learning in the school of the Holy Scripture, which witnesses to the Word of God; science laboring in the quest for truth, which is inescapably required of the community that is called by the Word of God" (Karl Barth).

Theology can be thought of as the Christian's discipleship of the mind. Yet theology is of importance beyond the Christian community. Those who are not Christians will be interested in learning what Christians believe, and why. ${ }^{30}$

McGrath melukiskan bahwa ilmu teologi adalah "the Christian's discipleship of the mind"; ilmu teologi adalah ke-murid-Kristus-an (artinya kedisiplinan iman yang serius) dalam hal pengolahan akal budi. Karena isi dari discipleship itu pada dasarnya adalah refleksi iman, maka dapatlah dikatakan di sini bahwa telogi adalah ilmu tentang refleksi-refleksi iman di dalam pergulatan hidup, dan bukan ilmu tentang agama yang refleksi-refleksi imannya sudah mengkristal menjadi aneka rumusan kepercayaan.

Ilmu teologi bukanlah ilmu agama. Ilmu teologi adalah ilmu tentang aneka refleksi iman yang membuat orang beragama. Teologi macam ini bukanlah ilmu yang objeknya adalah "Tuhan"; tetapi, ini adalah ilmu yang memeriksa dengan seksama tentang cara bicara tentang iman akan Tuhan yang melintasi sejarah berabad-abad, seperti yang dikemukakan oleh Armada Riyanto:

"Teologi" sebagai sebuah nama ilmu datang kemudian. Tidak serta merta "teologi" hadir seiring dengan kehadiran traktat tentang Tuhan. Jika Theos adalah Tuhan dalam bahasa Yunani, dan logos mengatakan disiplin ilmu; sudah barang tentu terjadi suatu revolusi pengertian yang berabad-abad lamanya. ${ }^{31}$

Yang diusahakan dalam ilmu teologi adalah kegiatan tiada henti untuk mempelajari fenomena dasariah tentang iman manusia. Fenomena dasariah itu adalah fakta bahwa manusia adalah suatu makhluk yang kehidupannya punya aspek iman. Isi dari aspek iman ini bukanlah soal beragama atau tidak. Isi dari aspek iman ini adalah soal komitmen untuk percaya dan memercayakan diri; dan ini adalah soal yang oleh Paul Tillich disebut dengan istilah "the ultimate concern" ${ }^{32}$ Iman adalah soal komitmen untuk percaya dan memercayakan diri, entah pada akhirnya berwujud keyakinan religius atau pun kebalikannya; entah pada akhirnya berwujud hidup religius yang sarat dengan sastra kesalehan atau pun kesalehan yang non-religius bahkan ateistik. Teologi memang bukan soal ilmu agama; teologi adalah ilmu tentang fenomena

\footnotetext{
${ }^{30}$ Alister E. McGrath, Theology: The Basics, 4th edition (Hoboken, NJ: John Wiley \& Son, 2018), xiii-xiv.

${ }^{31}$ Armada Riyanto, "Filsafat Divinitas (Keilahian) atau 'Teologi,'" Jurnal Teologi 4, no. 1 (2019): 1.

32 Paul Tillich, Systematic Theology Vol. 1 (Chicago, Illinois: University of Chicago Press, 1951), 11.
} 
pergulatan manusia dengan "the ultimate concern" yang pada akhirnya mendasari tindakan imannya.

Masalahnya adalah bahwa tindakan yang diambil berdasarkan sikap iman itu tidaklah selalu terjamin validitasnya sebagai hal yang benar. Ke-bisa-salah-an sikap iman itu membuat manusia selalu gelisah. Pada satu sisi, ia sangat percaya diri dengan sikap imannya; namun pada sisi yang lain ia pun selalu terusik dengan ketidak-percayaan atas validitas keyakinan imannya. Inilah yang membuat manusia selalu perlu berteologi. Manusia selalu butuh merefleksikan iman dan pengalaman imannya untuk menguji dan menimbang validitas keyakinannya.

Kebutuhan akan proses refleksi iman itulah yang melahirkan ilmu teologi. Ilmu ini punya sifat paradoksal. Di satu pihak, ilmu teologi membutuhkan refleksi iman yang sifatnya terukur dengan sederetan determinan dan kategori keilmuan yang bisa diverifikasi. ${ }^{33}$ Akan tetapi, di lain pihak, ilmu teologi bukan hanya sekadar pembelajaran dan penelitian, tetapi juga refleksi-refleksi keimanan di wilayah yang sifatnya "tidak terukur" secara matematis_-dalam artian lebih bersifat imajinatif, artistik, subjektif, dan berorientasi akan otentisitas—untuk membebaskan pengalaman iman dari mekanisme kesemuan yang kerap kali menjadi penyakit agama-agama yang mau tidak mau selalu harus terkait dan berurusan dengan perkara-perkara duniawi.

Ilmu teologi adalah refleksi iman atas berbagai data saintifik, untuk membawa manusia melalui imannya bergerak lebih jauh ke wilayah transendens: yang isinya adalah perjumpaan dengan Yang Diimani, yaitu Yang Ilahi. Dengan demikian, ilmu teologi secara metodologis bukanlah "ilmu agama" (yang mengklaim privilege agama wahyu) tetapi sungguh-sungguh "ilmu manusiawi" yang secara serius berusaha merefleksikan iman. Dengan prinsip metodologis ini, intensi usaha berolah ilmu teologi adalah mencari tilikan-tilikan (insights) yang lebih mendalam—dan penuh kekaguman —akan misteri-misteri keilahian di dalam anyaman hukum alam di wilayah kosmos yang cakupannya selalu melampaui aneka model keilmuan; sebagaimana dikemukakan oleh Denis Edwards:

...the vehicle for God's action in creation, grace, incarnation, and miracles is not simply the world our sciences model with our discovered laws of nature. Rather, the vehicle of God's selfmanifestations and actions, even in the case of miracles, is the wonderful, far more mysterious world of nature itself, including those aspects of the natural world that still escape our scientific modeling. ${ }^{34}$

Dengan kata lain, cakupan ilmu teologi selalu mulai dari "ilmu umum" dan kemudian memanfaatkan formasi kompetensi yang terbentuk di sana untuk merefleksikan iman ${ }^{35}$. Dari refleksi ini, berbagai topik ilmu teologi bermunculan seperti: paham Allah; paham akan teks kanonik; aneka paham akan ajaran iman, loci theologici; teologi akademik; tanggung jawab praktikal;

\footnotetext{
${ }^{3}$ Ilmu teologi pada dasarnya bersifat interdisipliner. Dalam membicarakan fenomena iman, ilmu teologi memerhatikan serius_-tanpa sikap subordinatif_apa-apa yang dikemukakan oleh berbagai disiplin ilmu. Misalnya: ilmu teologi sungguh-sungguh memerhatikan teori ekonomi "hukum pasar"-nya Friedrich Hayek dapat dibicarakan sebagai bagian dari refleksi iman di tengah sekularisme masyarakat (Christiaens 2019, 15-16); ilmu teologi sungguhsungguh memerhatikan teori evolusi dapat dibicarakan sebagai sarana yang canggih untuk memperdalam penghayatan iman: "salvation through evolution" (Curran 2019, 3); ilmu teologi sungguh-sungguh memerhatikan perkembangan paham antropologi untuk selalu menimbang-nimbang garis batas yang sifatnya dinamis antara wilayah dosa dan wilayah anugerah ilahi, misalnya dalam hal: seks, ras, dan budaya (Doak 2019, 529); dan, teologi pun sungguh-sungguh memerhatikan ukuran-ukuran empiris terhadap fenomena kejiwaan manusia sebagaimana dikembangkan dalam disiplin ilmu psikologi (Callaway and Strawn 2020, 14). Teologi bukanlah suatu wacana statis; teologi dibentuk oleh aneka penelitian yang sifatnya dinamis dengan beragam metode terhadap fenomena iman: "Whether theology is a discourse that attempts to speak about God or rather about religious human beings may well demarcate distinct theological methods" (Bergen 2019, 86).

${ }^{34}$ Denis Edwards, "Toward a Theology of Divine Action: William R. Stoeger, S.J., on the Laws of Nature," Theological Studies 76, no. 3 (July 2015): 501.

${ }^{35}$ Teologi bukanlah sekedar dinamika antara panalaran dan pengalaman (Winarto 2021, 4), tetapi seluk beluk refleksi keilmuan yang pada akhirnya diarahkan untuk merefleksikan iman. Teologi macam ini tidak bisa dikembangkan di lembaga-lembaga non-higher education. Sebab, pada dasarnya, teologi adalah kelanjutan dari filsafat, sosiologi, antropologi, biologi, fisika, dan semua disiplin "iptek" lainnya. Teologi tidak sama dengan praksis kerohanian, seperti menghafal ayat kitab suci melakukan doa pagi; sebab, teologi justru berfungsi untuk menilik secara kritikal-diskretif akan praksis kerohanian macam itu.
} 
tanggung jawab eksistensial; keterlibatan eklesial dan sosial; etos kerja profesional, existential dedication; keterlibatan kultural dan eksistensial; serta, mentalitas religius maupun teologis. ${ }^{36}$

\section{Filsafat Keilahian}

\section{Refleksi Iman dan Penajaman "Insight" Keilahian}

Dengan berlakunya UU No. 12 Tahun 2012, ilmu teologi tidak lagi ditemukan di wilayah daftar rumpun ilmu yang dikelola di bawah Kementerian Pendidikan/Ristekdikti/Dikbud. ${ }^{37}$ Lokus ilmu teologi sekarang berada di wilayah rumpun ilmu agama yang penyelenggaraan program studinya dibina oleh Kementerian Agama. Akan tetapi_-pada waktu artikel ini ditulis_proses perubahan nama program studi tersebut belum dapat dilayani secara lancar oleh Lembaga Layanan Pendidikan Tinggi. Lokus program studi "ilmu teologi" masih boleh berada di wilayah Kementerian Pendidikan dan Kebudayaan sekalipun isinya mestilah dipertegas: isinya bukanlah "ilmu agama" untuk "pendidikan keagamaan"; isinya adalah "ilmu filsafat keilahian" untuk "pendidikan umum".

Dalam kaitannya dengan watak dasar teologi yang merupakan refleksi atas iman, apakah filsafat keilahian itu?

Dalam artikel ini, istilah filsafat keilahian dimaksudkan sebagai nama lain untuk bidang studi yang lazim disebut sebagai filsafat ketuhanan. Namun, istilah "keilahian" dimunculkan untuk mengedepankan kedalaman yang lebih jauh kompleks daripada istilah "ketuhanan" yang terlanjur dicemari dengan berbagai ideologi yang membuat orang dapat terjerat ke aneka kasus penodaan agama. Istilah keilahian mau menunjuk wilayah yang lebih jauh dan lebih abstrak, tetapi dengan memerhatikan wilayah yang begitu dekat-konkret. Apa yang dimengerti sebagai "ketuhanan" itu sebetulnya adalah kedalaman-tak-berhingga yang bersemayam di setiap aspek kehidupan manusia yang sifatnya dekat-konkret. Kedalaman-tak-berhingga ini tidak muncul dengan begitu saja. Kedalaman-tak-berhingga ini kelihatan apabila orang melakukan tindakan berteologi, yaitu refleksi akal budi atas pengalaman imannya di wilayah kehidupan manusia yang begitu dekat-konkret. Refleksi akal budi atas pengalaman iman inilah yang disebut teologi, yang membuat orang melihat aspek-aspek keilahian di dalam aneka peristiwa insani dan gejala-gejala empiris-budayawi. Itulah sebabnya, teologi-di dalam artikel ini-disamakan dengan istilah filsafat keilahian.

\footnotetext{
${ }^{36}$ Michael Welker, "What Makes Theology Theology?," Theology Today 72, no. 2 (July 2015): 169.

${ }^{37}$ Secara kronologis, problematika penempatan lokus ilmu teologi pasca-UU 12/2012 dapat dilukiskan sebagai berikut. Pada tahun 2014, terbitlah Permendikbud 154/2014 tentang rumpun ilmu dan daftar gelar kesarjanaan. Pada tahun 2017, Permendikbud 154/2014 itu kemudian dicabut dan diganti dengan Permenristekdikti 15/2017; isi peraturan menteri ini pada dasarnya sama dengan yang digantikannya, yaitu tentang rumpun ilmu dan daftar gelar kesarjanaan. Di dalam Permenristekdikti 15/2017 ini, pada Pasal 7, terdapat klausul yang mewajibkan supaya "perguruan tinggi wajib menyesuaikan nama Program Studi dengan daftar nama Program Studi yang ditetapkan oleh Menteri berdasarkan Peraturan Menteri ini paling lambat 1 (satu) tahun sejak daftar nama Program Studi ditetapkan". Menghadapi situasi mendesak untuk segera menyesuaikan nama prodi teologi agar sesuai dengan peraturan menteri itu, sejumlah perguruan tinggi yang menyelenggarakan program studi teologi menyelenggarakan Lokakarya Filsafat Keilahian II, pada tanggal 22-23 Januari 2018, di Yogyakarta, untuk menetapkan rumusan keterampilan khusus dan rumusan pengetahuan untuk program studi "ilmu filsafat keilahian" (yaitu teologi) yang dikelolanya. Pada waktu itu, dengan mengacu Permenristekdikti 15/2017, program studi ilmu teologi mulai disebut dengan nama baru: filsafat keilahian. Namun, persoalannya, belum ada petunjuk teknis yang siap dijadikan acuan oleh lembaga-lembaga layanan pendidikan tinggi di Indonesia untuk melayani kebutuhan perguruan-perguruan tinggi di Indonesia untuk mengubah nama program studi menjadi sesuai dengan ketentuan Permenristekdikti 15/2017 tersebut di atas. Untuk mengatasi kesulitan itu, diterbitkanlah Permenristekdikti 33/2018. Oleh Permenristekdikti ini, pada Pasal 8, dinyatakan: "Perguruan tinggi yang telah memiliki izin program studi dapat mempertahankan nama program studi." Artinya, sekalipun dipahami sebagai rumpun ilmu "filsafat keilahian", program studi ilmu "teologi" yang sudah memiliki izin program studi tidak perlu segera mengurus penyesuaian nama program studinya dalam waktu dekat. Artinya, pada waktu artikel ini ditulis, ilmu "teologi" masih boleh berada di bawah binaan Kementerian Pendidikan dan Kebudayaan. Sekalipun penyelenggaraannya mesti sadar arah: yaitu bahwa ilmu teologi itu bukanlah semata-mata "ilmu keagamaan" sejauh diusahakan sebagai ilmu, yang berfungsi kritis terhadap agama, dengan metodologi filsafat keilahian.
} 
Karena wataknya yang selalu bersinggungan dengan misteri Yang Ilahi, makna teologi pun menjadi selalu bergerak melampaui aneka definisi. Selain bermakna sebagai suatu filsafat keilahian, teologi bisa dimengerti dengan cara lain yang berbeda. Teologi dapat dimengerti bukan sebagai suatu proses pencarian, tetapi sebagai seperangkat kalimat instruksional sarana pedagogis. Arti dari kata "instruksional" di sini adalah: bahwa ia berfungsi sebagai pasokan "instruksi" untuk membentuk "kon-struksi" yang menjelmakan bangunan pengertian. Untuk kepentingan pedagogis - demi memungkinkan terjadinya proses edukatif menurus asas-asas pembelajaran yang sifatnya alamiah-diperlukanlah aneka asupan "instruksioal" yang membuat pihak guru (naradidik) dapat mengerakkan proses didik yang melayani pihak murid (peserta didik).

Sebagai "rumpun ilmu agama", menurut istilah UU 12/2012, teologi menjadi ilmu yang berurusan dengan "keyakinan tentang ketuhanan atau ketauhidan serta teks-teks suci agama". ${ }^{38}$ Pemosisian ini adalah cara berpikir yang mengasumsikan adanya gugusan fakta "bentukan masa silam" yang memuat nilai luhur yang bernuansa universal. Fakta bentukan masa silam yang dianggap luhur-universal ini kerap kali disebut dengan istilah: "klasik". Sebagai suatu "rumpun ilmu agama", teologi adalah suatu fenomena akan hadirnya eksistensi "klasik" di tengah masyarakat.

Sekalipun memerhitungkan eksistensi "klasik" itu, pendekatan filsafat keilahian bersifat meninjau ulang signifikansi dari aneka properti "klasik" itu di wilayah "budaya" masyarakat. Secara par excellence, eksistensi "klasik" adalah sumber yang membuat wilayah "budaya" bisa hidup, tumbuh, dan berkembang di dalam sejarah yang dilintasinya. Akan tetapi, secara de facto, eksistensi "klasik" itu kerap kali menjadi sumber sikap-sikap yang diwarnai stereotip, primordialisme, fanatisme, bahkan bisa jadi takhayul, apabila relasi dialektis antara wilayah "klasik" dan "budaya" menjadi pudar.

Gejala ini dilihat oleh seorang teolog Katolik yang melihat bahwa teologi-sebagai filsafat keilahian—bermanfaat untuk menjembatani wilayah "kultural" dan wilayah "klasik" dengan cara menimbang-nimbang signifikansi/peran agama bagi kebudayaan manusia. ${ }^{39}$ Jika signifikansinya mengendor, teologi memeriksa apa-apa saja yang membuatnya kendor. Jika signifikansinya berlebihan sehingga menciptakan pseudo-sains, teologi memeriksa apa-apa saja yang membuatnya jadi kelewatan. Sebagai suatu filsafat keilahian, teologi adalah suatu disiplin ilmu pengetahuan yang amat dinamis; teologi berfungsi untuk menjembatani wilayah sains dan wilayah iman dengan cara berpikir yang sifatnya vivid dan kreatif. Tentang posisi teologi sebagai jembatan antara wilayah "kultural" dan wilayah "klasik" ini, Bernard Lonergan mengatakan:

A theology mediates between a cultural matrix and the significance and role of a religion in that matrix...When the classicist notion of culture prevails, theology is conceived as a permanent achievement, and then one discourses on its nature. When culture is conceived empirically, theology is known to be an ongoing process, and then one writes on its method. Method is not a set of rules to be followed meticulously by a dolt. It is a framework for collaborative creativity. ${ }^{40}$

Pada posisi sebagai jembatan antara wilayah "kultural" dan wilayah "klasik" tersebut, ilmu teologi hadir bukan semata-mata sebagai satu set kurilum yang siap diterapkan untuk kepentingan formasi kompetensi, transmisi informasi, ataupun pelatihan keterampilan. Lebih dari itu, ilmu teologi hadir sebagai "insight" (artinya cahaya kecerdasan, pengelihatan batin, visi internal) yang membuat iman semakin paham akan eksistensinya di depan Yang Ilahi. Bernard Lonergan mengilustrasikan hal ini sebagai sebagai cahaya naluri intelektual yang membuat seorang detektif dapat menemukan pelaku di balik kepingan-kepingan informasi yang ditemukannya. ${ }^{41}$ Kepingan-kepingan informasi itu hanyalah penuntun kepada jalannya peristiwa, sementara "insight" akan menuntun ke arah yang lebih jauh di balik jalannya peristiwa: yaitu menemukan "sang pelaku" (subjek, being, Dasein) di balik realitas yang sekadar tampak-

\footnotetext{
${ }^{38}$ Penjelasan UU No. 12 Tahun 2012, Pasal 10 ayat 2.

${ }^{39}$ Bernard J.F. Lonergan, Method in Theology (London: Darton, Longman and Todd, 1971), xi.

40 Ibid.

${ }^{41}$ Bernard J.F. Lonergan, Insight: A Study of Human Understanding (New York: Harper and Row, 1978), x.
} 
material. ${ }^{42}$ Sebagai ilmu pengetahuan yang diusakan di lingkungan pendidikan tinggi, ilmu teologi berurusan dengan pencarian "insight" itu. Ilmu teologi mengusahakan terbentuknya cahaya batin yang membuat orang berjumpa dengan Yang Diimani di balik aneka kepingan informasi tentang iman: pengalaman iman, sarana iman, dan tradisi iman. Melalui "insight" itu iman menjadi kesadaran yang menggerakkan aktivitas akal budi sehari-hari, termasuk dalam hal mengalami iman. Tentang "insight" ini, Bernard Lonergan mengatakan:

By insight, then, is meant not any act of attention or advertence or memory but supervening act of understanding... However, insight is not only a mental activity but also a constituent factor in human knowldege. It is not any recondite intuition but the familiar event that occurs easily and frequently in the moderately intelligent, rarely and with difficulty only in the very stupid. ${ }^{43}$

Sebuah pertanyaan kritis dapat diajukan terhadap penalaran di atas, yaitu: apakah dapat dikatakan bahwa soal "terbentuknya cahaya batin" itu adalah kekhasan dari ilmu teologi sebab ilmu-ilmu lainnya pun berpotensi besar untuk mengalaminya juga?

Jawabannya bersifat afirmatif, ya. Setiap ilmu yang diusahakan dengan sungguh-sungguh akan dapat membuahkan "insight" yang membuat orang dapat mengalami semacam cahaya batin tentang seluk-beluk perkara di bidang keilmuan yang digelutinya. Misalnya, seorang ahli mesin jet dapat lebih memahami gejala-gejala kerusakan mesin pesawat terbang dibandingkan seorang tukang sapu biasa yang tidak pernah belajar apa-apa tentang engineering.

Akan tetapi, berbeda dengan ilmu-ilmu yang lain, ilmu teologi secara khusus berusaha merefleksikan iman sedemikian rupa sehingga "insight" yang terbentuk atasnya akan terarah pada tantangan untuk bersikap penuh tanggung-jawab terhadap Yang Diimani. Tantangan ini sarat dengan makna eksistensial. Tantangan tersebut menggerakkan diri seorang subjek untuk bersentuhan dengan sumber-sumber gairah di kedalaman eksistensinya, dan untuk berjuang keras menciptakan aneka konstruksi ekspresi iman agar secara kreatif gerak-gerik Yang Ilahi, atau Yang Diimani, dapat diikuti di dunia manusia yang berwatak insani. ${ }^{44}$ Dalam pergerakan tersebut, seorang beriman yang mengusahakan ilmu teologi menjadi dapat bergerak bebas, baik di dalam atau pun di luar agama; ia akan mengalami iman dengan cara unik yang melampui agama.

Keunikan ilmu teologi tersebut membuatnya bukan sekadar bagian dari "rumpun ilmu agama" akan tetapi terlebih adalah wujud akademik dari usaha berolah filsafat keilahian. Melalui usaha olah filsafat keilahian ini, iman akan dialami-dengan subjektivitas autentik-bukan hanya sekadar informasi tentang Yang Ilahi, akan tetapi sebagai inspirasi "dari" Yang Ilahi. Iman itu dialami bukan sekadar aneka konstruksi gagasan keagamaan akan tetapi sebagai "interiority" (ruang batin) yang secara inspiratif menjadi sumber daya hidup dan kreativita. ${ }^{45}$

Dengan lain perkataan, sebagai suatu filsafat keilahian, ilmu teologi berpotensi untuk memfasilitasi "rumpun ilmu agama" agar tidak terpenjara oleh batasan-batasan agama semata. Sebagai suatu filsafat keilahian, ilmu teologi dapat mengolah suatu gerak bolak-balik antara posisi di domain "rumpun ilmu agama" dan posisi di domain "rumpun ilmu humaniora". Sebagai suatu filsafat keilahian, ilmu teologi amat bermanfaat untuk menjernihkan "insight" keagamaan dan untuk mencari "interiority" (ruang batin) yang aktif dan cerdas serta mampu mengkritik radikalisme agama. Dengan lain kata, dengan metode filsafat keilahian, ilmu teologi dapat digerakkan ke wilayah yang sifatnya dinamis dan dialektis: yaitu wilayah kediaman "insight" yang menjadi sumber inspirasi dan kedalaman (i.e., "interiority") hidup insani manusia: yang

42 Lih. Ted Peters, "The Transcendence of the Self in Light of the Hard Problem: A Response to Bas van Fraassen," Nova et Vetera 17, no. 2 (March 2019): 400.

43 Bernard J.F. Lonergan, Insight: A Study of Human Understanding (New York: Harper and Row, 1978), x-xi.

44 Arti istilah insani di sini adalah ciptaan yang personalitasnya selalu terhubung dengan Sang Pencipta sehingga berpotensi untuk terus bertumbuh-berkembang ke wilayah transendental. Istilah "insan" dipakai dengan pengandaian adanya ever-present dialog "insan-Khalik". Sebagai sosok insan, "human being" itu bukanlah sekedar spesies instrumental tetapi "wajah" kehadiran misteri ilahi yang selalu gelisah mencari Sang Pencipta-nya.

45 Hugo A Meynell, The Theology of Bernard Lonergan, AAR Studies in Religion 42 (Atlanta, Georgia: Scholars Press, 1986), 47. 
wajar, yang bersahaja, yang cinta kemanusiaan, yang mampu mengkritik kebodohan agama tanpa kehilangan pengelihatan akan dimensi-dimensi misteri keilahian.

\section{Spiritualitas}

\section{IImu Teologi dan Spiritualitas: Iman yang Mencari Raga}

Wilayah kediaman "insight" yang sarat dengan sumber inspirasi dan kedalaman itu kerap kali disebut dengan nama spiritualitas. Istilah spiritualitas ini amatlah kompleks maknanya, sehingga ia menjadi nyaris berfungsi seperti "tong sampah": segala hal bisa dimasukkan ke dalamnya. Istilah spiritualitas dapat dipakai untuk menyebut aneka hal yang diasumsikan bersifat "inner" dan substansial, seperti: jiwa, psikologi, mentalitas, roh, nyawa, autentisitas, etos, kultur, kekhasan tradisi, nilai-nilai (values), inti, esensi, substansi, dasar eksistensi, dan sebagainya. Dalam tulisan ini, istilah spiritualitas dimaknai sebagai wilayah terbitnya inspirasi. ${ }^{46}$

Dalam kaitannya dengan ilmu teologi dan metode filsafat keilahian, wilayah terbitnya inspirasi-yang disebut spiritualitas-ini dapat ditemukan dalam fenomena iman yang aktif menggerakkan kehidupan. Wilayah yang disebut spiritualitas ini adalah fenomena iman yang tidak mau tinggal di dalam kegelapan. Wilayah spiritualitas ini adalah iman yang menjelma jadi kehendak dan hasrat menggebu untuk mencecap citarasa kehidupan dan mengaktualisasikan eksistensinya. Spiritualitas adalah iman yang mencari raga_iman yang mencari tubuh daging insani-sehingga pada akhirnya pada akhirnya iman itu dapat dialami secara konkret, dapat dikomunikasikan kepada dunia, dan dapat diwariskan menjadi sumber inspirasi hidup dari generasi ke generasi.

Proses "mencari raga" yang digulati oleh iman di wilayah perbincangan yang disebut spiritualitas ini bukanlah perkara yang sederhana. Kandungan maknanya amat sangat kompleks. Kompleksitas makna pada istilah spiritualitas ini dikemukakan oleh seorang ahli mistisisme yang melihat bahwa spiritualitas adalah perkara yang selalu menciptakan kerumitan. ${ }^{47}$ Baik ketika didefinisikan dengan cakupan spesifik maupun ketika dikonsepkan dengan cakupan universal, istilah spiritualitas selalu merucut dari kesepakatan universal: "The usefulness of the term 'spirituality'... is coupled with a singular resistance to easy definition or universal agreement." ${ }^{48}$ Oleh sebab itu, sebelum orang dapat berbincang-bincang dengan memakai istilah spiritualitas, orang itu kiranya berusaha terlebih dahulu untuk memperlihatkan duduk perkara dari makna kata "spiritualitas" yang hendak dipakainya untuk berpendapat.

Dengan sangat baik, Philip Sheldrake memaparkan duduk perkara dari pemakaian istilah spiritualitas itu di dalam sejarah tradisi kekristenan. ${ }^{49}$ Di dalam paparan itu dipaparkannya bahwa istilah spiritualitas muncul di dalam riwayat panjang antropologi Kristiani yang berusaha melukiskan cara Allah menghadirkan Diri-Ilahi-Nya agar dapat ditemukan oleh manusia di dalam kehidupan insani orang per orang atau pun kelompok. Riwayat panjang antropologi Kristiani itu diawali dengan pemakaian istilah spiritualitas dalam surat-surat Paulus yang melukiskan kontras antara hal yang spiritual dan hal yang bersifat daging. Cara berpikir kontras ini kemudian

\footnotetext{
${ }^{46}$ Etimology Online Dictionary website. "Religion," n.d. https://www.etymonline.com/search?q=inspiration (diakses 12 Juli 2021).

Istilah inspirasi berasal dari gagasan Latin in spirare, artinya meniup ke dalam. Istilah ini berasal dari metafora penciptaan manusia dalam Kejadian 2:7 (bahwa Tuhan Allah meniup—in spirare-lubang hidung manusia sehingga hadirlah nafas). Dengan memerhatikan metafora ini, istilah inspirasi dapat dimaknai sebagai peristiwa bangkitnya kesadaran insani manusia karena sentuhan aktivitas ilahi. Dalam tradisi Kristiani, aktivitas ilahi ini dilukiskan sebagai peletakan nafas Allah kedalam tubuh manusia; Allah menghadirkan Diri-Nya di dalam tubuh kehidupan manusia baik sebagai mikrokosmos atau pun makrokosmos. Dalam artian macam itu, hadirnya inspirasi adalah parameter paling real dari fenomena yang disebut spiritualitas.

${ }^{47}$ Bernard McGinn, "Introduction," in Christian Spirituality: Origins to the Twelfth Century, ed. Bernard McGinn, John Meyendorff, and Jean Leclercq, Volume 16 of World Spirituality: An Encyclopedic History of the Religious Quest (New York: Crossroad, 1986), xv-xxviii.

${ }^{48}$ Ibid., Xv.

${ }^{49}$ Philip Sheldrake, A Brief History of Spirituality (Malden, MA: Blackwell, 2007), 2-4.
} 
melahirkan masalah ketika kekristenan berhadapan dengan gnostisisme yang memanfaatkan cara berpikir Paulus tersebut untuk menolak paham inkarnasi Kristus.

Menurut Sheldrake, masalah gnostisisme ini kemudian dihadapi oleh para teolog pascaPaulus, yang lazim disebut sebagai para Bapa Gereja. ${ }^{50}$ Mereka mengembangkan cara pandang alternatif dalam melihat isu spiritualitas. Menurut mereka, spiritualitas itu bukanlah melulu kontras antara dunia daging dan dunia roh tetapi peristiwa hadirnya Roh Allah di dalam dunia daging. Spiritualitas adalah peristiwa di-in-spirare-nya ${ }^{51}$ dunia daging manusia. Ketika Roh Kudus hadir dan bersemayam di dalam dunia daging, baik dalam rupa tubuh insani individual_atau pun jagad kemanusiaan lain yang lebih besar-maka pada saat itulah Allah sungguh-sungguh hadir dan dapat ditemukan secara real oleh manusia.

Akan tetapi, ketika dunia gereja semakin menyatu dengan penyelenggaraan kekuasaan di kekaisaran Romawi Kudus (the Holy Roman Empire), cara berpikir para Bapa Gereja itu kemudian berevolusi menjadi pengagungan terhadap posisi Gereja institusional pada abad pertengahan. Pada abad pertengahan itu, istilah spiritualitas dimengerti sebagai semua properti Gereja: baik yang berupa orang, barang, atau pun ritual. Semua properti Gereja itu disebut spiritualitas karena di dalamnya ada terwujud peristiwa in-spirare Roh Kudus di dalam dunia daging manusia. Karena ada spiritualitas, maka dunia Gereja menjadi identik dengan Kerajaan Allah. Siapa melawan Gereja menjadi cenderung dianggap sebagai pihak yang melawan Allah.

Cara berpikir abad pertengahan itu ditolak mentah-mentah oleh kaum Reformasi pada abad keenam belas. Mereka menggulirkan isu predestinasi yang di luar jangkauan manusia, termasuk orang-orang yang ada di wilayah properti Gereja: yaitu para pejabat yang dipercayai sebagai orang yang mengalami in-spirare Roh Kudus. Isu predestinasi ini menghentak kesadaran zaman pada waktu itu. Dunia Gereja pun terbelah. Ada yang tetap percaya bahwa Gereja identik dengan Kerajaan Allah di bawah divine majesty yang memuat predestinasi; namun ada pihak lain yang mulai melihat bahwa Gereja itu tidak identik dengan Kerajaan Allah karena predestinasi itu letaknya "di langit" yang tak terjangkau oleh para pejabat gereja. Yang pertama menjadi tradisi Roma Katolik modern; yang kedua menjelma menjadi tradisi Protestan modern.

Keterbelahan dunia pada waktu itu berbuntut panjang. Istilah spiritualitas menjadi bersifat problematis dalam khazanah teologi pasca-Reformasi. Kubu Protestan enggan memakai kata spiritualitas itu, dan lebih memilih kata pietas. Kubu Katolik, yang juga mengalami proses reformasi gerejawi, pun lebih memilih mysticism. Kedua kata itu, yaitu pietas (artinya kesalehan) dan mysticism (artinya kebatinan), sama-sama menunjuk kepada wilayah afektif yang bersemayam di kedalaman rasa hidup insani manusia. Kedua kata itu sama-sama menunjuk ke wilayah: pengalaman akan Allah. Wilayah ini adalah genangan cinta-bakti dan keintiman rohani yang dialami oleh manusia perjumpaan dan persentuhannya dengan Yang Ilahi. Sekalipun kedua kata itu menunjuk hal yang sama, namun masing-masing telah menjadi terminologi yang memberi identitas. Kata pietas itu dipakai oleh orang Protestan; kata mysticism dipakai oleh orang Katolik.

Situasi kontras Protestan vs. Katolik tersebut, menurut Sandra Schneiders, baru berubah pada pasca-Perang Dunia Kedua. ${ }^{52}$ Gereja Katolik mulai menyebut orang-orang Protestan dengan sebutan saudara-saudari yang terpisah, sementara gereja-gereja Protestan pun mulai suka berkomuni dengan orang-orang Katolik. Dalam suasana kebersamaan itu, politik identitas bahasa yang mengitari kata pietas dan mysticism pun memudar. Orang mulai mencari kata baru yang bisa dipakai untuk berpikir bersama. Kata baru itu pun dicari dari zaman purba, yaitu istilah spiritualitas. Pada periode pasca-Perang Dunia Kedua, istilah spiritualitas banyak dipakai orang untuk menarik kontras: antara yang konstruktif dan yang esensial; antara yang empiris dan yang bersentuhan dengan kedalaman; antara yang sarat kata teologis dan yang sarat rasa iman. Istilah spiritualitas dipakai untuk menunjuk wilayah-wilayah yang sifatnya "lebih": misalnya lebih dari

\footnotetext{
${ }^{50}$ Ibid.

${ }^{51}$ Artinya diembusi, disemayami Roh Allah. (Lihat catatan kaki nomor 46.)

${ }^{52}$ Sandra M Schneiders, "Christian Spirituality: Definition, Methods and Types," in The New SCM Dictionary of Christian Spirituality, ed. Phillip Sheldrake (London: SCM, 2005), 3-4.
} 
sekedar agama, lebih dari sekedar rumusan iman, lebih dari sekedar pemikiran teologis, dan seterusnya. Istilah spiritualitas dipakai untuk menunjuk wilayah in-spirare yang dialami oleh manusia di dalam perjumpaannya dengan Yang Ilahi.

Dalam konteks perbincangan macam itulah, Schneiders mengusulkan suatu definisi yang menyatakan bahwa spiritualitas adalah lived experience, pengalaman yang dihidupi atau dihayati, yang di dalamnya terjadi "conscious involvement in the project of life integration through self-transcendence toward the ultimate value one perceives" ${ }^{53}$ Dalam artian macam itu, spiritualitas bukanlah sekedar motivasi akan tetapi pengalaman terinspirasi dari dalam. Spiritualitas adalah kesadaran insani yang membuat orang terpanggil dan tergerak untuk semakin mengintegrasikan diri dengan keutuhan — via integrasi-di mana diri dan personalitas manusia akan terus-menerus tumbuh dan berkembang ke wilayah yang semakin luas dan mendalam tanpa batas. ${ }^{54}$ Dalam metafora bahasa iman Kristiani, hal itu dapat dilukiskan sebagai gerak ikut Tuhan yang melintasi dunia ini dan mengajak manusia orang per orang untuk terlibat di dalam pergerakan-Nya.

Kata kunci untuk memaknai istilah spiritualitas dalam kerangka pemikiran itu adalah pada kata lived: penghayatan, proses menghidupi. Ini adalah proses mencecap citarasa eksistensial atas segala hal yang melibatkan iman, yang pada akhirnya akan berimplikasi pada pembentukan diri personal seseorang. ${ }^{55}$ Segala hal dapat terasa taste-nya sebagai pengalaman iman yang tidak melulu abstrak tetapi empiris (karena terasa taste-nya secara inderawi) dan eksistensial (karena terasa taste-nya secara autentik-terlibat). Itulah dimensi lived (penghayatan, proses menghidupi) yang-di bidang ilmu teologi-hadir sebagai medan perbincangan khas yang disebut spiritualitas. Bagaimanakah dimensi lived (penghayatan, proses menghidupi) ini dapat diusahakan sebagai ilmu teologi di tataran pendidikan tinggi? Jawabnya adalah dengan metode keilmuan yang signifikan, supaya teologi menjadi usaha filsafat keilahian yang bukan hanya merefleksikan iman akan tetapi juga menajamkan citarasa ilahi atas aneka objek studi baik untuk kepentingan pembelajaran, atau pengajaran, maupun penelitian.

Dalam bukunya Spirituality: Forms, Foundations, Methods, Kees Waaijman memaparkan secara esktensif bagaimana metode keilmuan dapat dikembangkan secara sistematis pada aneka riset di bidang spiritualitas. ${ }^{56}$ Mula-mula, ia memperlihatkan wilayah luas yang berisikan data melimpah tentang fenomena spiritualitas dengan berbagai definisinya. Apa pun definisinya, fenomena spiritualitas itu telah hadir di dalam sejarah peradaban manusia dalam aneka bentuk, lokus, dan metode. Selanjutnya, ia menguraikan secara terperinci aneka bentuk, lokus, dan metode yang selama ini dikembangkan dalam studi tentang fenomena spiritualitas.

Dalam hal bentuk, spiritualitas muncul dalam tiga wujud. ${ }^{57}$ Pertama, wujud spiritualitas dapat ditemukan dalam bentuk gerakan kaum awam. Siapa pun orangnya, ia punya kepentingan dengan fenomena spiritualitas. Kedua, wujud spiritualitas dapat ditemukan dalam bentuk gerakan kaum "terpelajar" (dalam arti yang mengkhususkan diri untuk mendalami suatu corak aliran atau tradisi spiritualitas yang khas). Pada wujud yang kedua ini, spiritualitas ditemukan dalam gerakan-gerakan kaum "profesional" (artinya yang mendedikasikan diri secara jangka panjang) yang melahirkan tradisi-tradisi besar. Dari jajaran kaum "profesional" ini muncullah lembaga-lembaga besar yang menghadirkan aliran-aliran keagamaan atau pun tradisi-tradisi hidup religius. Ketiga, wujud spiritualitas dapat ditemukan dalam bentuk gerakan-gerakan counter movement (kontra-kemapanan). Hal ini terjadi ketika warisan-warisan emansipatoris tidak lagi meneruskan semangat mula-mulanya, sehingga lahirlah orang-orang tertentu-dari suatu

\footnotetext{
53 Ibid., 5.

${ }^{54}$ Paul Gondreau, "The Passions and the Moral Life: Appreciating the Originality of Aquinas," The Thomist: A Speculative Quarterly Review 71, no. 3 (March 2007): 450.

${ }^{55}$ Mary Frohlich, "Spirit, Spirituality, and Contemplative Method," Spiritus: A Journal of Christian Spirituality 20, no. 1 (2020): 41.

${ }^{56}$ Kees Waaijman, Spirituality: Forms, Foundations, Methods (Leuven: Peeters, 2002).

${ }^{57}$ Ibid., 9-304.
} 
kurun waktu tertentu-yang mencoba untuk menemukan semangat hidup baru yang mencoba melahirkan cara hidup alternatif yang patut dipikirkan oleh khalayak umum.

Dalam hal lokus, yang oleh Waaijman disebut "foundations", fenomena spiritualitas muncul dalam lima tempat kehadiran. ${ }^{58}$ la bisa muncul di dalam praksis, di dalam wacana teoritis, di dalam wilayah riset tentang transformasi hidup manusia, di dalam wilayah pengembangan kebijaksanaan hidup, dan di wilayah pendidikan tinggi yang wujudnya adalah disiplin akademik tentang ilmu spiritualitas.

Akhirnya, dalam hal metode, Waaijman memperlihatkan empat wilayah metodologis dari riset-riset di bidang ilmu spiritualitas. ${ }^{59}$ Wilayah riset yang pertama adalah pada penelitianpenelitian yang sifatnya deskriptif. Di sini, bidang studi spiritualitas diusahakan melalui aneka penelitian yang berusaha mendeskripsikan aneka corak kerohanian dalam hidup manusia. Wilayah riset yang kedua adalah pada penelitian-penelitian yang sifatnya hermeneutis. Di sini, bidang studi spiritualitas diusahakan melalui proses pembacaan naskah-naskah klasik yang berasal dari berbagai zaman untuk memetik berbagai pesan maupun tema kerohanian di dalamnya. Wilayah riset yang ketiga adalah pada penelitian-penelitian yang sifatnya konstruktif, yang berurusan dengan sistematika. Di sini, bidang studi spiritualitas diusahakan melalui proses penyusunan aneka konstruksi kerohanian dengan meminjam berbagai perspektif keilmuan secara interdisipliner. Dan pada akhirnya, wilayah riset yang keempat adalah pada penelitian-penelitian yang sifatnya mistagogis. Di sini, bidang studi spiritualitas diusahakan untuk kepentingan pendalaman iman yang membuatnya lebih dekat pada wilayah teologi operatif.

Dari paparan tersebut di atas, kiranya menjadi jelas bahwa melalui pendekatan filsafat keilahian, ilmu teologi bukanlah sekadar kajian atas "keyakinan tentang ketuhanan atau ketauhidan serta teks-teks suci agama" yang domainnya dapat ditunjuk secara spesifik melalui otoritas institusi keagamaan tertentu. Melalui usaha filsafat keilahian, ilmu teologi dapat digerakkan ke kawasan yang lebih luas dan lebih dalam-melampaui batasan-batasan agama institusionaluntuk mencari "insight" akan aneka wujud spiritualitas yang menjadi sumper inspirasi dan kedalaman hidup insani manusia.

\section{Rekapitulasi Kreatif}

\section{Ilmu Teologi sebagai Filsafat Keilahian demi Pendidikan Kristiani (Christian-values Education)}

Sistem pendidikan nasional yang berkembang pada dua dasawarsa terakhir ini tampaknya mencerminkan optimisme untuk mengintegrasikan secara sekaligus-ke dalam dunia pendidikan-aspek iptek dengan aspek keagamaan. Hal ini dilakukan dengan merumuskan cakupan sistem pendidikan nasional yang terdiri atas: pendidikan umum, pendidikan kejuruan, pendidikan profesi, pendidikan vokasi, dan pendidikan keagamaan. ${ }^{60}$

Bagi kalangan Islami, sistem pendidikan nasional perlu dikelola sedemikian rupa supaya mengakhiri supremasi "pendidikan iptek" atas wilayah-wilayah "pendidikan keagamaan" yang selama ini telah hidup di tengah masyarakat dalam wujud madrasah dan pesantren. Pendidikan dipahami sebagai proses yang menghubungkan proses pembelajaran dengan ruang laboratorium dan ruang doa. Ini adalah suatu proses yang bukan melulu saintifik tetapi juga estetik:

Pendidikan adalah keindahan proses belajar mengajar dengan pendekatan manusianya (man centered), dan bukan sekadar memindahkan otak dari kepala kepala atau mengalihakn mesin ke tangan, dan sebaliknya. Pendidikan lebih dari itu, pendidikan menjadikan manusia mampu menaklukkan masa depan dan menaklukkan dirinya sendiri dengan daya pikir, daya dzikir, dan daya ciptanya. ${ }^{61}$

\footnotetext{
58 Ibid., 305-592

${ }^{59}$ Ibid. 593-976.

${ }^{60}$ UU 20/2003, Pasal 15.

${ }^{61}$ Irja Putra Pratama and Raden Fatah Palembang, "Reformasi Pendidikan Islam Di Indonesia," Raden Fatah: Jurnal Pendidikan Agama Islam 1, no. 2 (2019): 121.
} 
Bagi kalangan Kristen, cara berpikir sistem pendidikan nasional itu akan jadi masuk akal sejauh tidak diciptakan struktur dan terminologi yang disejajarkan dengan kekhasan dunia pendidikan yang telah berurat-berakar di kalangan Islami. Bagi kalangan Kristen, pendidikan itu akan bersifat integratif_-artinya mampu mengintegrasikan aspek iptek dan keagamaan—apabila pada akhirnya berfungsi efektif untuk memfasilitasi pertumbuhan dan perkembangan kepribadian manusia secara utuh: baik jasmani maupun rohani, baik sisi insaninya maupun berbagai aspek keilahiannya. Integrasi itu selalu "mulai" dari inisiatif Yang Ilahi, yang dialami secara personal sebagai pengalaman religius dengan tanda khas: rasa kagum akan sentuhan kasih ilahi. ${ }^{62}$ Sebagai strategi untuk menyemai kemanusiaan yang semakin sadar akan hadirnya Yang Ilahi di tengah-tengah dunia manusia-yang dibahasakan sebagai integrasi antara aspek iptek dan aspek keagamaan di dalam dunia pendidikan—cara berpikir sistem pendidikan nasional itu amat masuk akal dan dapat dipahami oleh kalangan Kristen.

Sejauh ini, di kalangan Kristen, telah mengembangkan usaha integratif macam itu dengan memakai istilah Pendidikan Kristiani (atau disingkat PK, Christian-values education). Ini bukanlah pendidikan agama Kristen; tetapi, ini adalah pendidikan yang melibatkan aspek eksistensial diri manusia yang disebut iman. Aspek eksistensial ini tidak selalu tampil dalam kemasan agama formal, seperti: bicara saleh, pakai asesoris salib, atau membawa-bawa Alkitab entah ayatnya saja atau pun lengkap dengan buku komplitnya. Aspek eksistensial dalam PK ini muncul dalam wujud pribadi jujur/autentik (i.e., sosok insani-personal, human person) yang ingatan, harapan, dan atensinya disemayami oleh nilai-nilai iman Kristiani dalam menekuni jalannya peroses pendidikan: entah sebagai peserta didik, naradidik/guru, atau pun elemen-elemen pendukung pendidikan lainnya. Dengan demikian, integrasi yang namanya PK ini sebetulnya adalau suatu iklim dan kultur pendidikan, yang dibentuk dan difasilitasi oleh aneka infrastruktur. Sayangnya, integrasi yang namanya PK ini sering kali hanya diukur gejala "lembaga"-nya saja. Sebagaimana dilihat oleh Justitia Hattu, di gereja, PK itu dilihat hanya sebagai "lembaga" sekolah minggu; dan, di sekolah, PK itu dilihat hanya sebagai "lembaga" yang namanya pendidikan agama Kristen dan yang difasilitasi oleh seorang guru tertentu. ${ }^{63}$ Oleh sebab itu, terjadinya integrasi antara "iptek" dan "keimanan" — dalam wujud iklim dan kultur pendidikan yang namanya PK, Christian-values education-perlu diusahakan dengan arah pendekatan holistik yang mencakup aspek-aspek: formal, nonformal, dan informal. ${ }^{64}$ Melalui pendekatan holistik itu, Bensen Sidjabat membayangkan PK sebagai sarana pengintegrasi tiga ranah teologi, yaitu: gereja, sekolah, dan masyarakat. ${ }^{65}$

Dengan lain kata, apa yang disebut sebagai Pendidikan Kristiani itu pada dasarnya adalah pendidikan nilai, ${ }^{66}$ yang tidak mugkin dikerjakan dengan cara mentransmisikan sederetan rumusrumus moral, tetapi yang senantiasa membutuhkan proses merambatkan "spirit"—artinya mata air inspirasi yang tidak pernah kering-melalui pengalaman-pengalaman personal akan keintiman afektif di dalam keterlibatan sosial yang semakin menajamkan citarasa seseorang akan hadirnya Yang Ilahi di dalam segala hal. ${ }^{67}$ Apa yang diarah oleh Pendidikan Kristiani ini kiranya

\footnotetext{
${ }^{62}$ Christopher Woznicki, "The Awe of the Lord Is the Beginning of Knowledge: The Significance of Awe for Theological Epistemology," The Expository Times 131, no. 4 (July 2020): 157.

${ }^{63}$ Justitia Fox Dei Hattu, "Keterkaitan Pendidikan Kristiani Di Sekolah Dan Gereja," Indonesian Journal of Theology 7, no. 1 (2019): 28.

${ }^{64}$ Binsen S Sidjabat, "Meretas Polarisasi Pendidikan Kristiani: Sebuah Pengantar Tentang Arah Pendidikan Kristiani Di Gereja, Akademia, Dan Ruang Publik," Indonesian Journal of Theology 7, no. 1 (2019): 10.

${ }^{65}$ Ibid., 9.

${ }^{66}$ Yornan Masinambow and Yosef Nasrani, "Pendidikan Kristiani Sebagai Sarana Pembentukan Spiritualitas Generasi Milenial," Pasca: Jurnal Teologi Dan Pendidikan Agama Kristen 17, no. 1 (2021): 74.

${ }^{67}$ Yang Ilahi tidak pernah ditemukan secara langsung sebagai objek yang siap diukur. Relasi dengan Yang Ilahi selalu hadir dalam wujud refleksi atas pengalaman-pengalaman personal maupun sosial (i.e., relasi horizontal): “. . . hidup beragama itu selalu terkait dengan kehidupan bersama dan bukan hanya menjalin relasi vertikal dengan Tuhan saja" (Prabowo 2021, 31). Yang Ilahi itu ditemukan di dalam pengalaman manusia 'diembusi nafas' (i.e., diin-spirare) oleh Sang Pencipta yang membuatnya mengalami: bangkitnya kesadaran, kegairahan, kebebasan, dan autentisitas diri yang sarat dengan panggilan dan perutusan dari lubuk kedalaman jiwa insani (instrumental, personal, sosial).
} 
sejalan dengan apa yang diarah oleh UU 20/2003, Pasal 36, yaitu: iman, takwa, dan akhlak mulia.

Apa yang dituntut oleh undang-undang-dengan kemasan terminologi yang sedikit-banyak diwarnai oleh corak Islami-kiranya dapat pula ditemukan di dunia pendidikan yang diselenggarakan oleh kalangan Kristen. Akan tetapi, proses penemuannya tidak bisa dilakukan berdasarkan pencocokan terminologis yang dilakukan secara serta-merta (i.e., semena-mena), seperti dengan memaksakan pemakaian istilah "teologi" ke wilayah pendidikan keagamaan Kristen. ${ }^{68}$

Tanpa harus memaksakan pemakaian kata "teologi" ke wilayah pendidikan dasar dan menengah, amanat sistem pendidikan nasional yang perlu dikembangkan di dunia pendidikan Kristen—baik dalam wujud pendidikan agama atau pun pendidikan keagamaan Kristen—kiranya dapat ditemukan dengan mengembangkan praksis "pendidikan Kristiani" (PK, Christian-values education) yang menyemai dan menumbuhkan spiritualitas. Istilah "spiritualitas" di sini menunjuk kepada wacana dan wahana dengan berbagai lembaga dan infrastrukturnya yang arah pengelolaannya adalah terciptanya iklim dan kultur pendidikan yang sarat dengan nilai-nilai keimanan Kristiani. ${ }^{69}$

Dalam konteks penyemaian spiritualitas itu, penyelenggaraan pendidikan agama kiranya perlu disoroti dengan hati-hati. Tujuan pendidikan agama bukanlah untuk membuat orang merasa bangga akan pengetahuan keagamaannya; melainkan, tujuan pendidikan agama adalah membuat orang semakin mengenal kedalaman hati agamanya. Tujuan pendidikan agama adalah membuat orang semakin berbahagia di dalam perjumpaan dengan Yang Ilahi menurut tata cara agamanya.

Untuk itu, pendidikan agama perlu memperlengkapi orang dengan keberanian untuk menanyakan aneka ambivalensi dan paradoks yang selalu ada dalam setiap agama. Keberanian untuk bertanya itu akan menolongnya lebih paham, lebih mendalam, dan lebih menemukan kemurnian di dalam beragama. Dengan pendidikan agama macam itu, orang bisa diperlengkapi dengan akal budi personal yang terus bertumbuh dan berkembang. Hal ini akan membuatnya mampu menangkal paham-paham radikal yang berseliweran di mana-mana dan yang membuat orang merasa takut: misalnya takut bertanya, takut dianggap menyimpang, takut dianggap bidah, takut dianggap murtad, dan takut dianggap kafir. Dengan kata lain, tujuan pendidikan agama adalah membuat orang menjadi semakin merdeka hati nuraninya, dan menjadi semakin autentik jati diri personalnya, di dalam pencariannya akan Yang Ilahi.

Pendidikan agama itu bisa dikerjakan, paling tidak, dalam tiga moda: learning about, learning from, dan learning into. ${ }^{70}$ Yang pertama ("learning about") dilakukan oleh orang-orang yang bukan pemeluk suatu agama dengan narasumber yang bukan dari pemeluk suatu agama. Yang kedua ("learning from") dilakukan oleh mereka yang bukan pemeluk suatu agama, tetapi menerima informasi dari narasumber yang berasal dari suatu pemeluk agama. Yang terakhir ("learning into") dilakukan oleh orang-orang yang ingin masuk suatu agama. Ketiga moda tersebut sama pentingnya dan amat diperlukan untuk membuat peserta didik semakin memahami fenomena agama di dalam dunia manusia yang amat luas dan multiaspek.

Dalam konteks masyarakat Indonesia majemuk yang berdasarkan Pancasila, cara penyelenggaraan pendidikan agama dengan tiga moda ini kiranya dapat dikembangkan secara

\footnotetext{
${ }^{68}$ Lihat PP 55/2007.

${ }^{69}$ Lihat pembahasan di atas tentang penelitian spiritualitas yang dikembangkan oleh Kees Waaijman di atas.

${ }^{70}$ Menurut seorang peneliti Denmark, Karna Kjeldsen, pendidikan agama selalu bersifat problematik karena aspek "outsider" dan "insider" sulit dikompromikan. Di tengah kesulitan itu, pendidikan agama muncul dalam tiga pilihan praksis: apakah akan berwujud learning about, ataukah learning from, ataukah learning into suatu agama (Kjeldsen 2019, 13). Yang pertama, learning about, adalah praksis pendidikan agama yang dilakukan oleh sesama "outsider" atau orang-orang yang mengambil jarak terhadap apa yang dipelajarinya. Yang kedua, learning from, adalah praksis pendidikan agama yang dilakukan oleh sesama "insider" atau orang-orang yang terlibat secara eksistensial dengan suatu agama yang sedang dipelajari. Sedangkan yang ketiga, learning into, adalah praksis pendidikan agama yang dilakukan dalam rangka masuknya seorang "outsider" menjadi penganut suatu agama; ini melahirkan isu lain yang kemudian akan disebut-sebut entah sebagai pertobatan, pemurtadan, atau pemakaian kehendak bebas personal.
} 
seimbang, terukur, dan terhormat di dalam sistem pendidikan nasional. Hal ini akan membuka jalan yang lebih luas untuk meretas berbagai sekat keagamaan di dalam masyarakat, supaya nasionalitas bangsa Indonesia tumbuh sehat di zaman yang terus-menerus berubah. Untuk itu, penyelenggaraan pendidikan agama kiranya dapat diperlengkapi dengan visi pendidikan nilai: entah itu disebut sebagai olah-spiritualitas, olah-filsafat-keilahian, atau pun olah-teologi.

\section{KESIMPULAN}

Sampai pada titik ini kiranya dapat disimpulkan bahwa lokus ilmu teologi-dalam tradisi keilmuan yang hidup dalam tradisi Kristen/Katolik-tidaklah seperti yang dibayangkan oleh UU 12/2012 berdasarkan cara pandang PP 55/2007 dan Permenag-permenag turunannya. Teologi bukanlah suatu ilmu seperti yang dikembangkan di lingkungan madrasah dan pesantren. Teologi adalah suatu filsafat keilahian yang meresapi banyak dimensi iman manusia yang selalu mencari akan Yang Ilahi. Cakupannya luas sekali: bukan cuma sekadar ilmu agama, tetapi terutama ilmu tentang kritik terhadap agama dan tentang usaha-usaha integratif terhadap agama. Luasnya cakupan ini membuat teologi tidak dapat dipelajari di tataran pendidikan dasar atau pun menengah. Pada tataran pendidikan dasar dan menengah itu yang perlu diusahakan adalah pengenalan ilmu-ilmu umum dan humaniora, supaya kelak cakrawala keilmuannya dapat dipergunakan untuk mengembangkan pemikiran sintetik yang berupa filsafat keilahian. Arah yang ditunjuk oleh PP 55/2007 dan Permenag-permenag turunannya tentang penyelenggaraan "SD Teologi Kristen, SMP Teologi Kristen, Sekolah Menengah Teologi Kristen, dan Sekolah Kejuruan Teologi Kristen" adalah sesuatu yang absurd.

Meskipun demikian, sementara revisi perundang-undangan perlu diusahakan lebih lanjut, usaha kreatif untuk menghadapi situasi sulit ini masih cukup luas ruang lingkupnya. Ilmu teologi dapat dikembangkan di berbagai wilayah keilmuan, entah itu sebagai "ilmu agama" atau pun sebagai "ilmu umum/humaniora", sesuai dengan watak dasariahnya sebagai refleksi atas iman manusia. Disiplin ilmu teologi dapat dibina oleh Kementrian Agama, ketika ia diarahkan sebagai usaha pengelolaan wilayah "ilmu keagamaan". Akan tetapi, disiplin ilmu teologi pun dapat terus dibina oleh Kementrian Pendidikan, ketika ia diarahkan sebagai usaha pengembakan kritikagama dengan metodologi filsafat keilahian. Lebih jauh lagi, apa pun namanya, di mana pun lokusnya, ilmu teologi tetap dapat dikembangkan dengan beragam metode untuk melayani pendidikan spiritualitas atau pendidikan nilai.

\section{REFERENSI}

Adiprasetya, Joas. Gereja Pascapandemi Merengkuh Kerapuhan. Jakarta: BPK Gunung Mulia, 2021.

Amin, Muhammad. "Kedudukan Akal dalam Islam." Tarbawi: Jurnal Pendidikan Agama Islam 3, no. 1 (2018): 79-92.

AS, Nasruddin. "Info Arkeologis dalam Al-Quran." Dalam Kajian Ilmu Sosial dan Humaniora dalam Perspektif Al-Quran, ed. Mukhtaruddin, 131-68. Syiah Kuala, Banda Aceh: Bandar Publishing, 2016.

Bergen, Jeremy M. "Theology as Interpretive, Critical, and Constructive: Presidential Addresses to the Canadian Theological Society, 1990-2016." Studies in Religion/Sciences Religieuses 48, no. 1 (July 2019): 77-96.

Brink, Gijsbert van den. "How Theology Stopped Being Regina Scientiarum—and How Its Story Continues." Studies in Christian Ethics 32, no. 4 (July 2019): 442-54.

Callaway, Kutter, and Brad Strawn. "Experimental Theology: Theological Anthropology and the Psychological Sciences." Journal of Psychology and Theology 48, no. 1 (July 2020): 3-17.

Christiaens, Tim. "Hayek's Vicarious Secularization of Providential Theology." Philosophy \& Social Criticism 45, no. 1 (July 2019): 71-95.

Curran, Ian. "Theology, Evolution, and the Figural Imagination: Teilhard de Chardin and His Theological Critics." Irish Theological Quarterly 84, no. 3 (July 2019): 287-304. 
Doak, Mary. "Sex, Race, and Culture: Constructing Theological Anthropology for the TwentyFirst Century." Theological Studies 80, no. 3 (July 2019): 508-29.

Edwards, Denis. "Toward a Theology of Divine Action: William R. Stoeger, S.J., on the Laws of Nature." Theological Studies 76, no. 3 (July 2015): 485-502.

Frohlich, Mary. "Spirit, Spirituality, and Contemplative Method." Spiritus: A Journal of Christian Spirituality 20, no. 1 (2020): 31-44.

Gilman, Samuel. Revealed Religion: A Dudleian Lecture. Boston: W.M. Crosby and H.P Nichols, 1848.

Gondreau, Paul. "The Passions and the Moral Life: Appreciating the Originality of Aquinas." The Thomist: A Speculative Quarterly Review 71, no. 3 (March 2007): 419-50.

Hattu, Justitia Fox Dei. "Keterkaitan Pendidikan Kristiani Di Sekolah Dan Gereja." Indonesian Journal of Theology 7, no. 1 (2019): 25-45.

Hehanussa, Jozef M.N. "Dualisme Tata Kelola Pendidikan Tinggi Teologi Indonesia." Kompas, 2017.

Kjeldsen, Karna. "A Study-of-Religion(s)-Based Religion Education: Skills, Knowledge, and Aims." CEPS Journal 9, no. 4 (2019): 11-29.

Lase, Evasari Kristiani, dan Friska Juliana Purba. "Alkitab sebagai Sumber Pengetahuan Sejati dalam Pendidikan Kristen di Sekolah Kristen: Sebuah Kajian Epistemologi." Jurnal Abdiel 4, no. 2 (2020): 149-66. Heuken, Adolf. Spiritualitas Kristiani: Pemekaran Hidup Rohani Selama Dua Puluh Abad. Jakarta: Cipta Loka Caraka, 2002.

Lonergan, Bernard J.F. Insight: A Study of Human Understanding. New York: Harper and Row, 1978.

- Method in Theology. London: Darton, Longman and Todd, 1971.

Manan, Abdul. "Ritual dan Institusi dalam Islam." Dalam Kajian Ilmu Sosial dan Humaniora dalam Perspektif Al-Quran, ed. Mukhtaruddin, 21-40. Syiah Kuala, Banda Aceh: Bandar Publishing, 2016.

Masinambow, Yornan, dan Yosef Nasrani. "Pendidikan Kristiani sebagai Sarana Pembentukan Spiritualitas Generasi Milenial." Pasca: Jurnal Teologi dan Pendidikan Agama Kristen 17, no. 1 (2021): 64-81.

McGinn, Bernard. "Introduction." In Christian Spirituality: Origins to the Twelfth Century, edited by Bernard McGinn, John Meyendorff, and Jean Leclercq, xv-xxiii. Volume 16 of World Spirituality: An Encyclopedic History of the Religious Quest. New York: Crossroad, 1986.

McGrath, Alister E. Theology: The Basics. 4th ed. Hoboken, NJ: John Wiley \& Son, 2018.

Meynell, Hugo A. The Theology of Bernard Lonergan. AAR Studies in Religion 42. Atlanta, Georgia: Scholars Press, 1986.

Muchsin, Misri A. "Nilai Filosofis Historis Dalam Al-Quran." Dalam Kajian Ilmu Sosial dan Humaniora dalam Perspektif Al-Quran, ed. Mukhtaruddin, 1-20. Syiah Kuala, Banda Aceh: Bandar Publishing, 2016.

Online Etymology Dictionary. "Religion," n.d. https://www.etymonline.com/search?q=religion (accessed on July 28, 2021).

Peraturan Menteri Agama. 2010. Nomor 16, tentang Pengelolaan Pendidikan Agama pada Sekolah.

Peraturan Menteri Agama. 2012. Nomor 7, tentang Pendidikan Keagamaan Kristen.

Peraturan Menteri Agama. 2016. Nomor 27, tentang Pendidikan Keagamaan Kristen.

Peraturan Menteri Pendidikan dan Kebudayaan. 2014. Nomor 154, tentang Rumpun IImu Pengetahuan dan Teknologi serta Gelar Lulusan Perguruan Tinggi.

Peraturan Menteri Ristekdikti. 2017. Nomor 15, tentang Penamaan Program Studi pada Perguruan Tinggi.

Peraturan Menteri Ristekdikti. 2018. Nomor 33, tentang Penamaan Program Studi pada Perguruan Tinggi. 
Peraturan Pemerintah. 2007. Nomor 55, tentang Pendidikan Agama dan Pendidikan Keagamaan.

Rachmadi, Simon. "Theologia in Loco" di tengah Jalinan Antar-peradaban. Jakarta: BPK Gunung Mulia, 2019.

Remi, Ahmad. "Klasifikasi Agama," Majelis Penulis: Majelis Ukhuwah Penulis Bersyariah, 2012. https://majelispenulis.blogspot.com/2012/04/klasifikasi-agama.html (diakses 28 Juli 2021).

Peters, Ted. "The Transcendence of the Self in Light of the Hard Problem: A Response to Bas van

Fraassen." Nova et Vetera 17, no. 2 (March 2019): 391-400.

Prabowo, Hubertus Aditya. "Multikulturalisme dan Dialog dalam Pendidikan Agama Katolik." Jurnal Teologi 10, no. 1 (2021): 19-34.

Pratama, Irja Putra, dan Raden Fatah Palembang. "Reformasi Pendidikan Islam di Indonesia." Raden Fatah: Jurnal Pendidikan Agama Islam 1, no. 2 (2019): 117-27.

Riyanto, Armada. "Filsafat Divinitas (Keilahian) atau 'Teologi.'" Jurnal Teologi 4, no. 1 (2019): $57-72$.

Schneiders, Sandra M. "Christian Spirituality: Definition, Methods and Types." In The New SCM Dictionary of Christian Spirituality, edited by Phillip Sheldrake, 1-6. London: SCM, 2005.

Sheldrake, Philip. A Brief History of Spirituality. Malden, MA: Blackwell, 2007.

Sidjabat, Binsen S. "Meretas Polarisasi Pendidikan Kristiani: Sebuah Pengantar tentang Arah Pendidikan Kristiani di Gereja, Akademia, dan Ruang Publik." Indonesian Journal of Theology 7, no. 1 (2019): 7-24.

Sofyan, Fahmi. "Gaya Bahasa Kinayah dalam Rethorika Al-Quran: Sebuah Pendekatan Balaghah." Dalam Kajian Ilmu Sosial dan Humaniora dalam Perspektif Al-Quran, ed. Mukhtaruddin, 69-98. Syiah Kuala, Banda Aceh: Bandar Publishing, 2016.

Tamrin, Abu. "Relasi Ilmu, Filsafat dan Agama dalam Dimensi Filsafat Ilmu." Salam: Jurnal Sosial Dan Budaya Syar-i 6, no. 1 (2019): 71-96.

Tarigan, Musa S. "Kebenaran Allah Sebagai Dasar Pendidikan Kristen." JOHME: Journal of Holistic Mathematics Education 3, no. 1 (2019): 80-95.

Tillich, Paul. Systematic Theology Vol. 1. Chicago, Illinois: University of Chicago Press, 1951. Undang-Undang. 2003. Nomor 20, tentang Sistem Pendidikan Nasional.

Undang-Undang. 2012. Nomor 12, tentang Pendidikan Tinggi.

Waaijman, Kees. Spirituality: Forms, Foundations, Methods. Leuven: Peeters, 2002.

Wallace, William. Hegel's Philosophy of Mind. Oxfod: Clarendon Press, 1894.

Welker, Michael. "What Makes Theology Theology?" Theology Today 72, no. 2 (July 2015): 160-69.

Winarto, Amos. Penelitian Ilmu Teologi. Yogyakarta: Kanisius, 2021.

Woznicki, Christopher. "The Awe of the Lord is the Beginning of Knowledge: The Significance of Awe for Theological Epistemology." The Expository Times 131, no. 4 (July 2020): 15359. 